\title{
RESISTÊNCIA À BARBÁRIE A PARTIR DE UMA BIBLIOTECA ESCOLAR EM UM CONTEXTO DE VULNERABILIDADE SOCIAL
}

\author{
SABRINe Lino PINTO \\ SÔNIA CRISTINA VERMELHO \\ Universidade Federal do Rio de Janeiro (UFRJ), Rio de Janeiro, Rio \\ de Janeiro, Brasil
}

\begin{abstract}
Resumo: O objetivo deste trabalho é apresentar reflexões em torno da experiência de utilização da biblioteca como uma forma de resistência à barbárie em uma escola pública numa favela na cidade do Rio de Janeiro. Pensamos que seja um espaço para construir experiências voltadas à formação crítica, visando explicitar as desigualdades e mobilizar um conjunto de estratégias com o objetivo de transformação da realidade. O método é a pesquisa qualitativa, do tipo pesquisa-formação, com uso de diário de campo elaborado mediante as observações das atividades realizadas na biblioteca durante o ano de 2017. As conclusões levam-nos a acreditar que a biblioteca, como extensão da sala de aula, é um diferencial que permite ir além das experiências vinculadas ao ensino tradicional e mecânico e apresenta-se como espaço social de valorização de ideais democráticos.
\end{abstract}

Palavras-Chave: Educação. Biblioteca escolar. Violência. Teoria Crítica.

INTRODUÇÃO

O presente trabalho é parte de uma pesquisa longitudinal na modalidade de pesquisa participante, desenvolvida em uma escola municipal de ensino fundamental na cidade do Rio de Janeiro. Em 2017, foram iniciados 
os trabalhos na biblioteca, denominada de Sala de Leitura. Importante salientar que todas as atividades desenvolvidas foram previamente discutidas com a direção da escola e com outros interessados. Neste sentido, a presente pesquisa é resultado da identificação de uma possibilidade de contribuir com a melhoria da educação, numa articulação da universidade com a escola, em que pesquisadoras, professores e gestores estavam envolvidos. Para situar o contexto da pesquisa, faremos uma descrição do bairro onde se insere a escola na qual trabalhamos.

Manguinhos, localizado na zona norte da cidade do Rio de Janeiro, ocupa, atualmente, uma área situada entre a Avenida Brasil, a Avenida dos Democráticos, a Linha Amarela e o Ramal da Linha Ferroviária de Minério do Arará (TRINDADE, 2013). A ocupação residencial do bairro ocorreu inicialmente de forma lenta no início do século XX, expandindo-se a partir dos anos 50. No início do século XXI, as novas construções impactaram aspectos estruturais e relações sociais e de poder, desencadeando uma nova fase para Manguinhos, marcada pelo cruzamento de conquistas de melhorias de vida, como as indenizações pelas antigas habitações e as negociações das novas, a garantia do aluguel social, interrompido em 2016-2017, e, por outro lado, da insegurança e da instabilidade, como a existência de um provável tráfico de influências e de traficantes de drogas e de milicianos (FERNANDES; COSTA, 2013).

\section{A EDUCAÇÃO PARA EMANCIPAÇÃO}

O pensamento de Paulo Freire acerca do letramento científico com base numa educação crítica e libertária, que dê condições de transformação da realidade do indivíduo, impacta sobremaneira o ensino, que, nesta pesquisa, é discutido sob a perspectiva da Teoria Crítica. Ter esse olhar nos permite compreender a relação da ideologia das classes dominantes com os conteúdos e currículos, uma vez que essas classes têm por objetivo reproduzir e manter os mecanismos e propósitos do sistema capitalista. Sendo assim, ampliamos o leque acerca do ensino crítico, preconizando os fortes argumentos e as abordagens dos teóricos da Escola de Frankfurt, que, embora versassem acerca das condições sociais, econômicas e culturais de meados do século passado, vislumbraram o caminho que a sociedade industrial tomaria nos anos à frente, mostrando-nos contemporâneos ao nos trazer elementos para compreender a atualidade.

Marcuse (1973) descreve com criticidade o modo como o desenvolvimento científico e tecnológico veio se desenvolvendo desde meados do século passado e afirma que o mundo está sob a influência 
do que ele chama de ideologia da sociedade industrial. Nessa sociedade, toda a produção e toda a distribuição dos produtos e serviços não estão desvinculadas dos aspectos sociais e políticos, pois o trabalho assalariado, os meios de comunicação de massa, as mercadorias e o seu consumo, os bens de produção e os aparatos científicos e tecnológicos são produzidos e estão a serviço da manutenção e da ampliação do capitalismo e do consumismo, como fins em si mesmos, sem que haja a necessária reflexão sobre a natureza do trabalho, do desenvolvimento exagerado do consumo e das intenções e dos objetivos da ciência. Segundo os pensadores da segunda geração da Escola de Frankfurt, observa-se que a sociedade atual está assentada numa racionalidade instrumental, que, ao contrário de levar a humanidade à sua emancipação, a mantém numa relação de subserviência em relação à técnica e à ciência, as quais, por sua vez, se vinculam à economia (ADORNO; HORKHEIMER, 1986).

Todo esse sistema se mantém por meio de um processo de socialização que tem criado estratégias sofisticadas ao longo do tempo para suprimir as contradições sociais do imaginário social, mediante uma ideologia mantida pelos meios de comunicação de massa, pelas produções culturais e artísticas e por todo aquele que se integra ao sistema e o reproduz no seu cotidiano. O funcionamento desse processo social se legitima segundo a lógica da "indústria cultural", conceito cunhado em meados do século passado por Adorno e Horkheimer (1947). Esse conceito busca explicar que a cultura, antes um espaço de resistência e de luta diante das injustiças sociais, sob a lógica do capital foi dominada pelo mercado, direcionando a cultura cada vez mais para se sustentar pelo consumismo, segundo uma ideologia que tende a mascarar e a ajustar tudo ao existente e cujo resultado leva à não realização do indivíduo autônomo.

Nesse contexto, a sociedade acaba por aceitar tudo que é novo proposto pelo mercado, criando uma falsa consciência de que os produtos ou serviços são realmente necessários para a sua sobrevivência, sem questionamentos ou reflexões, submetendo, assim, todo o aparato social à lógica e ao controle do sistema de produção. Dessa forma, pode-se afirmar a existência, neste século XXI, de uma sociedade profundamente contraditória, que, de um lado, é detentora de uma tecnologia de ponta, a qual exige dos indivíduos um sacrifício demasiado para mantê-la e perpetua a supressão das potencialidades humanas, e, de outro, se prolonga e se conserva por esses próprios indivíduos que sofrem as conseqüências dos padrões impostos por absorverem essa ideologia de forma alienada (ADORNO, 1971; ADORNO, HORKHEIMER, 1973; MARCUSE, 1973). 
De acordo com Marcuse (1973), a sociedade está sujeita a formas de controle social que tentam encobrir o processo histórico das necessidades humanas, pois o mecanismo de produção e seus resultantes serviços e mercadorias instituem o sistema social como um todo, aprisionando as pessoas à falsa consciência de que há uma aceitável racionalidade nesse modelo de sistema social. Essa falsa consciência é determinada pela interação entre os aspectos psíquico-afetivo e social e se sustenta por impelir o individualismo na manutenção da vida, em detrimento do coletivo. Caracteriza-se pelo elevado consumo de bens e serviços que acabam por nivelar o contraste entre as necessidades impostas e as possíveis e as que são atendidas e as que não são. Nesse bojo, os meios de comunicação se apresentam como um mecanismo de mediação dos sujeitos com as necessidades sociais do sistema produtivo, priorizando o acentuado consumo como garantia do desenvolvimento social e individual, o que, consequentemente, resulta na limitação do pensamento reflexivo do indivíduo, no seu poder de discernimento e na sua autonomia de decisão. Segundo Adorno (1995), isso leva à formação de uma sociedade composta por pessoas que se desviaram da consciência de si mesmas e absorvem e aceitam o todo social dentro de uma ideia de naturalidade.

Portanto, se faz necessário promover uma formação que estimule a consciência crítica em relação ao processo de manipulação ideológica, por meio do desenvolvimento do pensamento reflexivo, de explicitação das contradições sociais, o qual possibilite a compreensão das linguagens presentes no mundo e, por conseguinte, possa resultar em ações que contribuem para as transformações sociais necessárias para eliminar essas contradições. Para tanto, a escola pode ser apontada como instituição que promova um processo de leitura crítica da ciência e dos meios de comunicação de massa, cujas produções se constituem como espectros da sociedade. "Consideramos importantes os alertas que Adorno traz referentes à educação no tocante a saber se "[...] por meio da educação pode-se transformar algo de decisivo em relação à barbárie" (ADORNO, 1995, p. 155) e também suas críticas à manutenção da competitividade como instrumento central da educação e à punição e ao comportamento autoritário por parte dos professores e professoras. Para ele, e para nós do grupo de pesquisa, "[...] a barbárie continuará existindo enquanto persistirem no que têm de fundamental as condições que geram esta regressão" (ADORNO, 1995, p. 119)

Portanto, acreditamos que, como educadores-pesquisadores e sujeitos históricos, nosso papel seja atuar na sociedade para construir experiências educacionais dirigidas a uma autorreflexão crítica (ADORNO, 1995). Tanto na formação de professores quanto nas experiências com os 
estudantes, procuramos desmontar a ideia de que a educação se faz por meio de métodos severos, austeros, pois nos parece, concordando com Adorno, que isso é um ideal de educação completamente equivocado. Para tanto, consideramos ser de nossa responsabilidade atuar na perspectiva de uma educação política, explicitando o jogo de forças que atuam na sociedade. Nesse sentido, um educador brasileiro que se debruçou a buscar formas de atuar nessa direção foi Paulo Freire.

A pedagogia proposta por Paulo Freire nos parece ser capaz de orientar uma educação voltada para a formação crítica. De acordo com Freire (2005), para que os educandos desenvolvam em si a consciência crítica e assim se insiram no mundo, como transformadores dele, como sujeitos, é necessário que a educação tenha uma concepção problematizadora e libertadora, contrariando a visão "bancária" da educação. Enquanto a educação se entender como uma instituição de adaptação, de ajustamento do sujeito na sociedade, não haverá transformação e, nessa perspectiva educacional, o poder de criação dos educandos é anulado ou minimizado. Assim, será uma educação "[...] que estimula sua ingenuidade e não sua criticidade, [que] satisfaz aos interesses dos opressores: para estes, o fundamental não é o desnudamento do mundo, a sua transformação" (FREIRE, 2005, p. 69). A abordagem crítica que a escola precisa dar aos conteúdos científicos, inspirada em Paulo Freire, seria aquela capaz de explicar os fenômenos do mundo, da ciência advinda da razão instrumental. Porém, o que temos é uma escola que, ao invés de contestar, acaba por despolitizar esses conhecimentos e reforçar ainda mais a dinâmica social e econômica da sociedade, fomentando, por meio da técnica e da tecnologia, hábitos, costumes e valores da vida cotidiana, o que resulta na legitimação do funcionamento vigente do sistema.

Portanto, defendemos que a educação deva favorecer a formação da autonomia de pensamento e de ação e possibilitar a aprendizagem por meio da contradição, da investigação, da comunicação e do debate. E que, conforme Paulo Freire nos ensinou, por meio das palavrasmundo, ${ }^{1}$ seja capaz de dar significado ao conhecimento. Nesse sentido, em consonância com essa educação libertária e de palavramundo, enquadram-se os pressupostos frankfurtianos, por estarem contextualizados com a crítica à realidade social, o que coloca essa proposta de educação no campo de uma educação revolucionária, pois tem o potencial de transformar os sujeitos em sujeitos históricos, uma vez que o processo de aprendizagem é social e tanto quem aprende como quem ensina podem ambos aprenderem algo que não sabiam (FREIRE, 1978). 
Recorremos a esses autores para dialogar sobre o que compreendemos e defendemos para a educação e a sociedade em contraposição ao atual sistema capitalista, o qual permeia e dita as normas e os hábitos consumistas e nada democráticos que acabam por alimentar ainda mais a injustiça e a diferença social entre os indivíduos, em especial, produz a realidade dos jovens em situação de vulnerabilidade social, os quais acabam por receber o adjetivo de "em situação de vulnerabilidade social". Nesse bojo, relacionar a educação à luz de tais teóricos, que sugerem não só práticas pedagógicas que contemplem a contextualização, mas a desalienação e a transformação da realidade, significa trazer à tona a questão da subjetividade do indivíduo para que este tenha condições de compreender e desvelar de forma mais profunda todos os aspectos e entraves que impedem a sua formação crítica. Sob essa ótica, apresentamos, no próximo tópico, detalhes da realização desta pesquisa que contempla desde a descrição da coleta e da análise dos dados até a exposição dos efeitos da incursão em campo.

\section{Procedimentos metodológicos}

Nossa pesquisa se caracteriza como pesquisa participante, do tipo pesquisa-formação, dando mais atenção aos aspectos subjetivos da experiência e do comportamento humano. Para tanto, foram realizadas várias incursões no território educativo, com o objetivo de conhecer e acompanhar vividamente o cotidiano da escola e do seu corpo docente e discente até a consolidação de uma proposta voltada ao uso da biblioteca como alternativa metodológica para a educação. $O$ intuito foi refletir sobre o potencial desse espaço para estimular o interesse no estudo e criar experiências educativas que estimulassem o pensamento crítico, tanto diante dos materiais midiáticos e tecnológicos quanto sobre a realidade em que estão inseridos.

Os sujeitos da pesquisa foram os alunos do ensino fundamental, segundo ciclo, acompanhados pelos respectivos docentes de língua portuguesa, ciências e história. O corpus da pesquisa se compõe de 39 relatos na forma de diário de campo, produzidos entre os meses de março e novembro de 2017. Estão descritas, com base nas reflexões pessoais da pesquisadora, a partir das suas observações em campo, as atividades, as experiências, as apreensões e as impressões por parte dos alunos, além das dificuldades que, porventura, surgiram durante a execução da pesquisa. Para garantir a fidedignidade na coleta dos dados, essas descrições foram feitas durante as intervenções na biblioteca e também foram registradas, em alguns momentos, com fotos ou filmagens durante o trabalho de observação, ou imediatamente após, por meio de notas descritivas e analíticas. 
A análise desses relatos foi feita com a utilização do software Atlas.Ti, versão 6.0, empregado em pesquisa qualitativa para a análise de dados qualitativos. A primeira etapa contou com a criação das categorias previamente contempladas no problema e no objetivo da pesquisa e outras que foram sendo reveladas durante o processo de leitura e análise dos relatos. A etapa seguinte contou com a leitura dos trechos selecionados na etapa anterior para relacioná-los e organizá-los nas categorias, tanto para revelar a incidência de frequência dessas categorias, como também para procedermos à análise de conteúdo e relacionarmos os dados aos referenciais teóricos. Como técnica, utilizamos a análise de conteúdo temática proposta por Bardin (2009).

\section{RESULTADOS E DISCUSSÃO}

Antes de apresentar os resultados e a discussão com base nos dados obtidos nos registros do diário de campo e nas categorias criadas, se faz necessário relatar alguns fatos acerca da biblioteca e da escola em que foi realizada a pesquisa. Nos primeiros contatos e visitas informais realizados na escola, que ocorreram em fins do ano letivo de 2016, apuramos que os professores não vinham fazendo uso do acervo e do espaço da biblioteca, seja para pesquisa, estudo ou outras atividades educativas, culturais ou artísticas, seja para ações que consideramos como constituintes do processo de formação dos alunos. Também nos foi informado que a leitura era um problema a ser resolvido, pois, pela concepção das pessoas com as quais dialogamos sobre o assunto, havia um entendimento de que as crianças, em geral, não tinham interesse pela leitura. Porém, temos que ressaltar que havia, por parte da direção, a intenção de organizar o espaço durante as férias de final de ano, por meio da manutenção, limpeza e arrumação, para sua utilização como espaço de leitura e complementação dos estudos.

Esse objetivo não se concretizou de imediato, pois, por ocasião do nosso retorno em março de 2017, notamos que o espaço da biblioteca permanecia sem manutenção, funcionando como um depósito de livros, inclusive os livros didáticos do Programa Nacional do Livro Didático (PNLD) 2017-2019, os quais, embora novos, estavam empilhados no meio da sala, empoeirada e sem ventilação adequada. Porém, começamos assim mesmo por organizar o acervo por nossa conta. No decorrer das semanas, continuamos com a organização do acervo e a retirada dos livros didáticos. De alguma maneira, o grupo ficou receoso em relação à receptividade por parte da gestão à equipe da universidade para contribuir com a escola, pois experimentamos situações em que as relações entre ambas não ocorreram 
de maneira tranquila, tendo em vista uma certa desconfiança da escola sobre os reais interesses e intenções dos pesquisadores. Fomos surpreendidos, mas concordamos plenamente com o posicionamento adotado pelo corpo docente, que demarcou claramente que a escola não se colocava na condição de "objeto" de investigação. Nesse sentido, entendemos que uma relação de desconforto existiu nos primeiros momentos, pois algumas atividades que tentamos estimular inicialmente foram questionadas pelos gestores, como, por exemplo, o empréstimo dos livros aos alunos e alunas, que só foi retomado pela insistência destes. Todavia, com o tempo, conseguimos conquistar a confiança da gestão e dos professores, e a receptividade por parte deles obteve uma visível melhora, o que garantiu a realização da pesquisa e a intervenção no espaço.

A situação de acomodação inicial diante das dificuldades de manutenção da biblioteca aberta pode ser analisada à luz das discussões acerca do assujeitamento aos padrões determinados pelos interesses e pelas instituições sociais dominantes, como preconizado por Marcuse (1973). Entendemos que colocar-se contra a racionalidade do sistema não é uma tarefa simples. Diante de tantas dificuldades impostas aos gestores e docentes para manter aquele espaço aberto, estes acabam por se ajustar à falta de condições. Em função dessa situação, muitos alunos e alunas nunca haviam tido a experiência de entrar numa biblioteca; até desconheciam o fato de que a escola dispunha daquele espaço. Por isso, muitos, ao entrarem pela primeira vez no local, não sabiam como se comportar ali dentro e nem a função de um espaço como aquele, chegando ao ponto de questionarem se os livros estavam à venda ou eram para ser doados. Foi necessário explicar a cada novo aluno que ali entrava sobre a organização do acervo, o espaço e sua função e, mais do que isso, enfatizar que a presença deles era importante.

No que tange à categoria Conjuntura da Escola, por se tratar de um contexto considerado como de vulnerabilidade social, a realidade do território e a condição social dos alunos e alunas exercem uma potente influência sobre o seu comportamento. Não foram poucos os depoimentos de crianças que relataram o descaso na sua criação, com lares em que as relações eram difíceis, sem pessoas que assumissem os papéis materno e paterno, em algumas situações sob a guarda de outros membros da família, de vizinhos e amigos. Também, como já foi evidenciado em outros estudos, revelaram a facilidade de entrar para o tráfico de drogas e a prostituição, aspecto relacionado não somente à proximidade com esses elementos, mas também pela falta de horizonte para o futuro, que aponte possibilidades para além daquelas que eles vivem ali. Com isso, acabam por associar a melhoria de vida ao ingresso 
na criminalidade. Estar a escola posicionada próxima da Fundação Oswaldo Cruz (Fiocruz) ${ }^{2}$ acentua ainda mais duas realidades muito contrastantes: de um lado, uma escola de formação básica, fragilizada por um sistema de educação limitador e precário, permeado pelo medo e pela violência e, de outro lado, a poucos passos, uma instituição renomada, com segurança e infraestrutura de qualidade que remetem a outro mundo. Nem parece que ali do lado, na rua, as pessoas e, em especial, as crianças vivem em um clima de medo, tendo seus direitos cerceados, ficando claro que é imprescindível, por meio de uma educação revolucionária e libertadora (FREIRE, 1978), trabalhar com o que estiver ao nosso alcance para que seus sonhos, suas aspirações e seus desejos não se percam; eles precisam ter esperança. É nosso papel, como educadores e/ou militantes de movimentos sociais, contribuir para que as contradições sociais e suas mazelas sejam trazidas à tona e se tornem elementos de força e de luta contra a opressão do sistema.

Para ilustrar a categoria Conjuntura da Escola, traremos à atenção um episódio. No início do ano, fomos autorizados pela direção a distribuir os livros didáticos do PNLD 2017-2019 aos alunos, já que ocupavam um espaço considerável da biblioteca. Após alguns dias em que estávamos distribuindo os livros às crianças, a diretora nos informou que o dono de um ferro-velho localizado próximo foi à escola para falar que havia alunos vendendo os livros lá, mas que ele não estava comprando-os porque observou que eram novos. Mas que, ao fazer isso, os alunos passaram a jogá-los na rua, pois não podiam ser convertidos em dinheiro. Com isso, os usuários de drogas (crack) passaram a recolher os livros dos lixões e levá-los para vender no mesmo ferrovelho que, nesse caso, passou a aceitá-los porque ele não podia se recusar a comprar o material dos usuários de droga para não causar "problemas" com a comunidade. A diretora, quando nos informou sobre isso, deu a entender que esse comportamento representava a índole dos alunos e das alunas menosprezo para com os livros -, o qual, naquele contexto, levava a esse tipo de conduta. Por causa dessa situação, formos orientados a não mais distribuir os livros didáticos, para não causar esse transtorno ao dono do ferro-velho e, em consequência, boa parte das obras ainda continuam lá. ${ }^{3}$ Essa situação nos levou a algumas reflexões. Primeiramente, que o "livro" representava para as crianças uma fonte de renda, não uma fonte de informações; na "contabilidade da vida", fazia mais sentido transformá-los em dinheiro do que em conhecimento. Assim, o sentido que a cultura letrada atribuiu ao livro ao longo de sua história deixou de ter sentido para aquelas crianças, pois havia um desvinculamento entre o livro e a escola/sala de aula, pois, até então, nunca haviam sido usados em aula. Refletimos que esse episódio poderia indicar uma clivagem entre o leitor (alunos e alunas) e o livro. 
Como nos mostrou Chartier (1996), as práticas de leitura se alteraram ao longo do tempo mediante novos arranjos sociais em torno do livro e da configuração do próprio objeto em si; contudo, o ato de leitura implicava uma relação íntima do leitor com o livro. Consideramos que, ao fazer do livro somente um equivalente em dinheiro - o que ficou evidenciado pelo episódio relatado -, este se apresentou às crianças muito mais como valor de troca do que como valor de uso. Como mercadoria, reforçou que, como tal, "[...] é um objeto externo, uma coisa, a qual pelas suas propriedades satisfaz necessidades humanas de qualquer espécie. A natureza dessas necessidades, se elas se originam do estômago ou da fantasia, não altera nada na coisa" (MARX, 1985, p. 45).

Podemos dizer que a relação deles com os livros foi de estranhamento, de não reconhecimento de si naquele objeto, pois, como mercadoria, o trabalho humano é apagado, eliminado pela sociedade que atribui às contradições sociais um caráter probabilístico, de aleatoriedade da vida. Aquelas crianças que sentem fome diariamente, que desconhecem completamente o jogo econômico que as coloca naquele lugar, reconheciam naquele objeto algo que podia se converter em dinheiro. Podemos culpá-las? Certamente não, pois a lógica que a sociedade naturalizou como verdade última é esta: tudo pode ser convertido em capital. As crianças, tanto quanto aqueles livros, foram transformadas em mercadorias sem muito valor no mercado atual: crianças de favela que não têm futuro, não serão empreendedoras, bocas a serem alimentadas e com risco de se rebelarem contra o sistema. Assim como os livros, sem qualquer utilidade para uma sociedade que não quer que as pessoas pensem. Portanto, qual tipo de relação poderiam elas construir com o livro? Talvez a mesma que, em geral, demonstram em relação às suas vidas: algo sem valor algum... Situações como essa evidenciam que a violência simbólica, menos visível do que a violência física, está relacionada com as

[...] regressões psíquicas, necessárias em cada momento histórico à perpetuação desta sociedade. [...] Assim, o que pode gerar sofrimento psíquico - as neuroses - serve à manutenção social. Desse modo, não é possível pensar os sofrimentos e distúrbios psíquicos sem os relacionar com a força da sociedade derivada de sua necessidade de se conservar, e como suas instituições, tais como a família e a escola, são fundamentais para a formação individual, também colaboram com ambos - com o sofrimento psíquico e com a reprodução social (CROCHICK, 2017, p. 15).

Nesse episódio, o sofrimento causado pela miséria e pela fome, a certeza de sua inutilidade para essa sociedade como ser humano - sentimento presente de maneira muito forte naquelas crianças -, nos mostra os limites 
que essa educação, tal como promovida nas escolas, pode estar contribuindo de maneira sistemática com o aprofundamento da barbárie, pois "[...] se não gera imediatamente o fascismo, possibilitado por determinações sociais, contribui para sua conservação" (CROCHICK, 2017, p. 14)

$\mathrm{Na}$ categoria Insegurança da região é evidenciada pelos altos índices de conflitos armados, pois, além de ser uma das vias de escape para os caminhões de carga roubados, também apresenta inúmeros confrontos armados entre policiais e traficantes de drogas e até mesmo entre os grupos de traficantes. Durante os nove meses da pesquisa, houve muitos dias em que não foi possível comparecer devido à falta de segurança, ocasionada por operações policiais com incidência de tiroteios. Das 28 semanas, foram nove dias em que não pudemos comparecer porque as aulas haviam sido suspensas, em cinco dias as aulas foram interrompidas enquanto estávamos lá, e, em outros sete dias, foram ouvidos tiros nas proximidades da escola. Após um desses períodos em que as aulas foram suspensas, um aluno relatou a experiência que ele viveu. $O$ garoto, de 11/12 anos, relatou o seguinte: "Tia, ainda bem que você não estava aqui ontem!". E, quando indagado do porquê, ele continuou: "Muito tiro, tia, muito tiro! Nunca tinha ouvido tanto assim. Precisei me esconder debaixo do caminhão". Ele disse que estava acompanhado de um colega que o protegeu. "Vimos a polícia e os tiros foram bem perto da gente e fomos para debaixo do caminhão. Até vi as cápsulas pertinho da gente!" Na continuação da conversa, indagamos sobre a opinião da mãe dele sobre isso e ele confessou:"Não falei com ela, porque, se ela sabe que eu estava fora da escola nessa hora, vai me bater e brigar comigo e não vai deixar eu voltar mais [para a escola]".

Esse episódio, além de evidenciar o completo descaso da polícia em relação à população do local - pois entra atirando nas ruas das favelas onde vivem trabalhadores, idosos, crianças, sem qualquer relação com a criminalidade - também desnuda a complexidade de relações com que essas crianças têm de lidar no seu cotidiano. Elas não só tiveram de superar o terror gerado pelo conflito armado ao qual foram expostas, mas também resolver o problema causado em casa porque a escola havia liberado-as mais cedo - por conta dos conflitos armados -, uma vez que o fato de estar na rua naquela hora poderia ainda trazer mais violência quando chegassem em casa.. No caso desse aluno, especificamente, o medo teve de ser vivido e superado por ele mesmo, e as únicas pessoas com quem conseguiu conversar sobre o assunto fomos nós, que o atendemos na biblioteca no contraturno. Na escola, os demais colegas não têm escuta, pois também são vítimas. Os pais, como o garoto relatou, por razões que não nos cabe julgar, ao invés de oferecer alento 
e segurança, poderiam gerar ainda mais sofrimento. Como uma criança dessa idade lida com tamanha carga de violência física e simbólica?

São relatos que nos comoveram e nos deixaram paralisados, pois ficamos inseguros em relação a como agir diante dessa situação: não demonstrar nossos sentimentos para não reforçar um processo de vitimização que eles sofrem, o que amplia o estigma e o preconceito de que são alvo - eles são denominados de vulneráveis, portanto, em desvantagem social -, mas também não mostrar insensibilidade em face de tamanha violência, como o relatavam aquelas crianças. Lembrando as palavras de Adorno (1995a) acerca da falsidade da educação pela dureza, concordamos que:

A enaltecida dureza que a educação deve conseguir significa, pura e simplesmente, indiferença à dor. A propósito, não há muita distinção entre a dor própria e a alheia. Aquele que é duro consigo mesmo se arroga o direito de ser duro também com os demais e se vinga neles da dor que não pode manifestar, que teve que reprimir. Esse mecanismo deve ser conscientizado, assim como deve ser promovida uma educação que não premie a dor e a capacidade de suportá-la. Em outras palavras, a educação deveria levar a sério uma ideia que de nenhum modo é estranha à filosofia: $a$ angústia não deve ser reprimida (ADORNO, 1995a, p. 114, grifo nosso).

Apesar de nossa concordância com essa orientação de Adorno, a situação real problematizou nossa capacidade de lidar de maneira consciente com esse episódio. O que nos evidenciou a nossa própria fragilidade para fazer frente às situações cotidianas no âmbito da escola e a nossa condição de pesquisadores, ainda que tenhamos nos colocado na condição de pesquisadores-colaboradores na escola. Diante da incerteza em relação ao modo como a escola e a família atuam nessas situações, sentimo-nos imobilizados e muito pouco pudemos fazer, a não ser dar sentido à experiência pela qual aquelas crianças haviam passado e valorizá-la. Acolhemos seus relatos, indagamos sobre seus sentimentos, solidarizamo-nos com suas revoltas, seus medos. Mas sabíamos que no final do dia iríamos embora daquele lugar, enquanto aquelas crianças iriam enfrentar novamente os mesmos medos, as mesmas violências e reprisar os mesmos sofrimentos. Como de fato aconteceu. Durante várias semanas aqueles, meninos repetiram a história, reprisaram-na até que ou outro fato semelhante aconteceu, ou foi internalizada a angústia gerada pelo sofrimento. Sobre isso, a psicologia já nos mostrou que "quando a angústia não é reprimida, quando o indivíduo se permite realmente ter tanta angústia quanto esta realidade merece, então, provavelmente, desaparecerá grande parte do efeito destrutivo da angústia inconsciente e protelada" (ADORNO, 1995a, p. 114-115). Não temos condição 
de analisar se isso ocorreu com aquelas crianças, mas nos recolocou o desafio de pensar que "a educação só teria algum sentido como educação para uma autorreflexão crítica" (ADORNO, 1995a, p. 106). A angústia nossa diante do desafio de lidar com a expressão viva do que essa sociedade é capaz de fazer, de transformar a vida daquelas pessoas em nada, e a angústia delas diante dessa violência sem ter como objetivamente sair de tal situação demonstram o enorme desafio para todos nós em relação a nosso compromisso com a transformação social.

Pensamos que realizar uma educação revolucionária e libertadora, apoiada na concepção da superação da alienação (MARX, 1985; FREIRE, 1978) e da mais-repressão (MARCUSE, 1973) e na compreensão dos mecanismos da indústria cultural (ADORNO; HORKHEIMER, 1986) - cujas ideias, num plano geral, objetivam a superação da alienação do indivíduo, visando à transformação da sua realidade - , é uma tarefa cotidiana, que emerge em todos os momentos da experiência educacional e não somente nas salas de aula em torno dos conteúdos. Uma educação revolucionária e libertadora é uma prática social, mais do que uma pedagogia.

Quanto à categoria Predisposição à Violência, registramos, por diversas vezes, principalmente com as crianças do sexo masculino, simulações de lutas. Em alguns momentos, montavam o tapete de E.V.A. para funcionar como uma espécie de tatame e ficavam lutando MMA. Golpeavam-se fortemente, revelando que não era somente uma simulação, era uma luta real. Havia até apoio e torcida dos outros alunos que estavam assistindo. Mesmo sendo alertados para pararem, continuavam e diziam que estavam brincando. Uma outra brincadeira que faziam, relatada por um professor, embora não a tenhamos testemunhado, ocorria na quadra e era conhecida como "ronda", que simulava crime e venda de drogas, com dinheiro inclusive. Observamos que eles se ofendiam mutuamente, xingando-se, revidando, agindo com violência, dando tapas, chutes, correndo e jogando objetos uns nos outros, prática evidenciada não só entre os meninos, mas entre as meninas também. Era comum ouvir os alunos chamando colegas por apelidos depreciativos, dos quais eles não gostavam, gerando troca de ofensas. Muitos alunos pegavam os materiais dos colegas que, ao tentarem tomá-los de volta, acabavam quebrando-os, arrebentando-os ou rasgando-os.

Acontecia, com frequência, de um grupo tentar fazer um teatrinho e acabar sendo incomodado pelos colegas, impedindo-os de encenar até o fim. Também havia alunos que tentavam ler, mas não conseguiam porque os colegas não faziam silêncio ou os interrompiam. Dava-nos a impressão de que outras atividades (teatro, leitura) que não estivessem relacionadas à 
violência não eram aceitas pelos demais, eram desqualificadas e impedidas de acontecer. Foi com muita insistência, paciência e repetição de que era necessário o respeito aos demais colegas que fomos garantindo dentro da biblioteca o respeito a essas atividades. No final do ano, conseguimos preservar o lugar para práticas não violentas que, paulatinamente, passaram a ser aceitas por todos e ganhando mais adeptos. O que víamos naquele cenário era o reforço da violência que atinge a todos nós, mas com eles de maneira ampliada, explicitando o aspecto mais cruel do sistema social excludente e desigual da sociedade capitalista (MARCUSE, 1973).

Sobre esses episódios, temos algumas questões a considerar. Primeiramente, é a tendência à adesão aos coletivos, aspecto que Adorno aponta como um dos grandes desafios para a educação: fazer com que as pessoas não sigam cegamente os coletivos, transformando-se em "[...] algo quase material, desaparecendo como seres autodeterminados" (ADORNO, 1995a, p. 115). Para aquelas crianças, desenvolver comportamentos violentos, tais como aqueles vistos na mídia, nos games, em casa e na rua, acaba sendo um ato de reprodução cega daquilo que enxergam à sua volta. Fazer com que não reproduzam esses comportamentos coletivos de violência explícita nos parece ser um desafio enorme naquele lugar, tendo em vista dois aspectos: 1) a inserção no grupo social, que no caso da favela pode significar a garantia da integridade física, da vida mesmo, é uma necessidade relacionada à socialização, e 2) o fato de beirar ao cinismo de nossa parte considerar que, em nenhum momento da vida, aquelas crianças não precisarão ter habilidades físicas para se proteger da violência que é praticada sobre elas, seja ali na favela, seja em outro espaço. Parece-nos que desestimular esses comportamentos pura e simplesmente com o discurso da não violência também não possibilita que essas crianças desenvolvam em si mesmas mecanismos de autoproteção. O preconceito que sofrem fora dali, no impedimento e no cerceamento da liberdade de ir e vir, é decorrente da cor da pele, dos trajes que portam, da linguagem que utilizam, marcadores sociais que fazem com que, em algum ou em muitos momentos da vida, elas terão necessidade de se proteger da violência de que são vítimas.

Esse episódio nos remeteu à discussão de Adorno (1995) acerca da barbárie, de que a própria desbarbarização da sociedade não requer o abandono das afeições fortes e nem mesmo a eliminação da agressão. Segundo o autor, há barbárie onde há regressão à violência física primitiva, sem vinculação explícita com situações que justifiquem racionalmente esses comportamentos. Portanto, “[...] em circunstâncias em que a violência conduz inclusive a situações bem constrangedoras em contextos transparentes para 
a geração de condições humanas mais dignas, a violência não pode ser mais nem menos ser condenada como barbárie" (ADORNO, 1995, p. 159-160).

Isso nos leva a compreender aqueles comportamentos como práticas preparatórias para o enfrentamento da vida, de uma vida em que há poucos momentos sem que a violência física esteja presente. Sair de casa pela manhã e deparar-se com homens da polícia ou do exército fortemente armados adentrando a rua, tanques de guerra estacionados na frente da escola, sabendo que ao chegar na escola sofrerão outras violências, caso se comportem de maneira agressiva - até mesmo como forma de extravasar o medo - e que, no intervalo das aulas, as brincadeiras vão reproduzir atos de violência física aprendidos com os mais velhos ou com os "heróis" da mídia/ game são situações cotidianas enfrentadas por aquelas crianças que nos apresenta o desafio de compreender qual o papel e a função dessas práticas na economia psíquica delas. Concordamos com Adorno que:

[...] na luta contra a barbárie ou em sua eliminação existe um momento de revolta que poderia ele próprio ser designado como bárbaro, se partíssemos de um conceito formal de humanidade. Mas já que todos nós nos encontramos no contexto da culpabilidade do próprio sistema, ninguém está inteiramente livre de traços de barbárie, e tudo dependerá de orientar esses traços contra o princípio da barbárie, em vez de permitir seu curso em direção à desgraça (ADORNO, 1995, p. 158).

Portanto, para além das evidências em relação ao nosso papel no sentido de não estimular atitudes violentas, pensamos que seja fundamental compreender que esses comportamentos podem atuar como elementos formativos para uma vida que será toda ela perpassada pela violência física explícita. Não considerar esse aspecto seria, de nossa parte, diante do que vimos, esperar que aquelas crianças desenvolvam mecanismos de superação e de sublimação a partir de seus próprios instintos agressivos, os quais se aproximam à negação e à capacidade de identificação com a dor coletiva que eles sentem. Quando nos dizem "é só uma brincadeira!" talvez estejam afirmando que essa é a forma como se constroem coletivamente, uns ensinando aos outros como se defenderem da violência física praticada contra eles cotidianamente. Talvez essa seja a forma como se identifiquem, e a identificação com a dor alheia é uma das formas de se contrapor à frieza da sociedade atual. Nosso olhar externo provavelmente não conseguiu compreender que, naquele lugar, as relações sejam construídas com comportamentos que, a priori aos nossos olhos, sejam repreensíveis por, externamente, mostrar uma ação agressiva sobre o outro. Mas talvez essa agressão seja necessária tanto para a sobrevivência subjetiva quanto objetiva. 


\section{CONCLUSÕES}

Embora as fragilidades e os obstáculos sejam muitos, o fato de oportunizar ao aluno um espaço que promova a articulação de práticas pedagógicas com os conteúdos trabalhados em sala de aula, mediante o favorecimento do hábito de leitura como apropriação do mundo, pode tornar a biblioteca um diferencial que permita ir além do ensino tradicional e mecânico. Para os alunos, além da extensão da sala de aula, a biblioteca se apresentou como espaço de socialização e como uma possibilidade para o acesso ao conhecimento e ao prazer do hábito da leitura.

Nossas experiências com as crianças também nos oportunizaram refletir, à luz da Teoria Crítica, sobre a educação e os desafios cotidianos, a fim de proporcionar um processo formativo que contribua para a superação da injusta e cruel conjuntura da sociedade atual. Portanto, consideramos que a existência e a manutenção da biblioteca como um local de resistência e de enfrentamentos dentro do espaço escolar podem não só servir para uma educação comprometida com a realidade dos alunos, para que exercitem a sua curiosidade e a sua imaginação, reelaborando suas angústias e seus medos, mas também para que os alimentem de utopias, devolvendo-lhes o brilho no olhar, a capacidade de se compreender para além desse lugar que a sociedade os coloca, na marginalidade, não como criminosos, mas como inúteis dentro da lógica e da dinâmica de produção e consumo exacerbado. Entendemos que a biblioteca, por ser um espaço em que há possibilidade de transgredir as limitações impostas à sala de aula - tempos, conteúdos, avaliações etc. -, pode se constituir no contexto escolar como um espaço de práticas que se voltem à resistência contra a barbárie social. 
RESISTANCE TO BARBARIE FROM A SCHOOL LIBRARY IN A SOCIAL VULNERABILITY CONTEXT

ABSTRACT: This article presents reflections on the experience of using the library of a public school as a place of resistance to barbarism. We believe it is a good place to build critical education experiences, to explain inequalities and to mobilize strategies towards the transformation of reality. The research method is qualitative research, the field diary was used to record the activities carried out in the library during the year 2017. We conclude that the library, as an extension of the classroom, allows to overcome traditional and mechanical teaching and can be a social space of valorization of democratic ideals.

KEYWORDS: Education. School library. Violence. Critical theory.

\section{LA RESISTENCIA A LA BARBARIE A PARTIR DE UNA BIBLIOTECA ESCOLAR EN UN CONTEXTO DE VULNERABILIDAD SOCIAL}

RESUMEN: El objetivo de este trabajo es presentar reflexiones sobre la experiencia de la utilización de la biblioteca como forma de resistencia a la barbarie, en una escuela pública de un suburbio, de la ciudad de Río de Janeiro. Pensamos que debería ser un espacio para construir experiencias orientadas a la formación crítica, buscando explicar las desigualdades y movilizar un conjunto de estrategias que direccionen a la transformación de la realidad. El método es de la investigación cualitativa, del tipo investigación-formación, con el uso de un diario de campo obtenido a través de las observaciones de las actividades realizadas en la biblioteca durante el año 2017. Las conclusiones nos llevan a creer que la biblioteca, como extensión de la sala de clases es algo extra que permite ir más allá de las experiencias vinculadas a la enseñanza tradicional y mecánica, que se presenta como un espacio social de valorización de los ideales democráticos.

PalabRas clave: Educación. Biblioteca escolar. Violencia. Teoría Crítica.

\section{NotAs}

1. Neologismo criado por Paulo Freire para nomear os contatos iniciais do sujeito leitor com o mundo em suas múltiplas dimensões (DIÓGENES, 2010).

2. A Fiocruz é uma instituição de pesquisa e desenvolvimento em ciências, considerada uma das principais instituições mundiais de pesquisa em saúde pública. Tem como objetivos promover a saúde e o desenvolvimento social, gerar e difundir conhecimento científico e tecnológico e ser um agente da cidadania. Fonte: $<$ https:// portal.fiocruz.br/>. 
3. Em 2018, a situação felizmente se alterou. Os livros passaram a ser distribuídos nas salas de aula e lá permanecem para uso dos professores durante as aulas.

\section{AgradeCimentos}

O presente trabalho foi realizado com apoio da Coordenação de Aperfeiçoamento de Pessoal de Nível Superior - Brasil (CAPES) - Código de Financiamento 001.

\section{REFERÊNCIAS}

ADORNO, T. W. Teoria da la seudocultura. In: HORKHEIMER, M.; ADORNO, T. W. Sociologica. Madrid: Taurus, 1971.

. Educação e emancipação. Rio de Janeiro: Paz e Terra, 1995.

. Palavras e sinais: modelos críticos 2. Tradução: Maria Helena Ruschel. Petrópolis, RJ: Vozes, 1995a.

:; HORKHEIMER, M. Dialética do esclarecimento: fragmentos filosóficos. 2. ed. Tradução: Guido Antonio de Almeida. Rio de Janeiro: Jorge Zahar, 1986.

. (Org.). Temas básicos da sociologia. São Paulo: Cultrix; USP, 1973.

BARDIN, L. Análise de conteúdo. 19 ed. Lisboa, Portugal: Edições 70, 2009.

CHARTIER, R. Práticas de leitura. São Paulo: Estação Liberdade, 1996.

CROCHICK, J. L. Bullying, preconceito e desempenho escolar: uma nova perspectiva. São Paulo: Benjamin Editorial, 2017.

DIÓGENES, E. M. N. Paulo Freire: leitor da palavramundo. Debates em Educação, Maceió, v. 2, n. 3, jan./jun. 2010. Disponível em: <http://www.seer.ufal.br/index.php/debateseducacao/article/view/63/60>. Acesso em: 13 ago. 2018.

FERNANDES, T. M. COSTA, R. G. R. As comunidades de Manguinhos na história das favelas no Rio de Janeiro. Revista Tempo, v. 19, n. 34, p. 117-133, jan./jun. 2013.

FREIRE, P. Cartas à Guiné-Bissau: registros de uma experiência em processo.4. ed. Rio de Janeiro: Paz e Terra, 1978. (Coleção O mundo, hoje).

. Pedagogia do oprimido. 46. ed. São Paulo: Paz e Terra, 2005.

MARCUSE, H. A ideologia da sociedade industrial. 4. ed. Rio de Janeiro: Zahar Editores, 1973.

MARX, K. O capital: crítica da economia política. 2. ed. São Paulo: Nova Cultural, 1985. (Coleção Os economistas).

TRINDADE, C. P. da. Política pública e o direito à cidade em Manguinhos, Zona Norte do Rio de Janeiro. In: SIMPÓSIO NACIONAL DE HISTÓRIA, 27. 2013, Natal. Anais... 
Natal: SNH, 2013. Disponível em: <http://www.snh2013.anpuh.org/resources/ anais/27/1371340784_ARQUIVO_ClaudiaTrindadeAnpuh2013.pdf >. Acesso em: 21 jun. 2016.

Sabrine Lino PINTO: Doutoranda em Educação em Ciências e Saúde do Programa de Pós-graduação do NUTES-UFRJ. Mestra em Educação em Ciências e Matemática do Programa EDUCIMAT do Instituto Federal do Espírito Santo - IFES (2014). Possui graduação em Biblioteconomia pela Universidade Federal do Espírito Santo (2005) e é pós-graduada com especialização em Biblioteca Escolar pelo CESAT. Atualmente é bibliotecária-documentalista do Instituto Federal de Educação, Ciência e Tecnologia do Espírito Santo. Tem experiência na área de Ciência da Informação, Educação e na Área de Administração.

E-mail: brinevix@gmail.com

Sônia Cristina Vermelho: Possui graduação em Processamento de Dados pela Universidade Positivo (1993), mestrado em Educação: História, Política, Sociedade pela Pontifícia Universidade Católica de São Paulo (1998) e doutorado em Educação: História, Política, Sociedade pela Pontifícia Universidade Católica de São Paulo (2003). Fez Pós-Doutorado no INESC/Universidade do Porto, Portugal, no Laboratório de Sistemas de Informação e Computação Gráfica (2014). Atualmente é professora adjunta da Universidade Federal do Rio de Janeiro, no Programa de Pós-Graduação em Educação em Ciências e Saúde, vinculada ao Núcleo de Tecnologia Educacional para Saúde NUTES, no Laboratório de Linguagens e Mediações. Tem experiência na área de Educação superior e pós-graduação. As áreas de interesse de pesquisa: Mídia-Educação, Educação em Ciências e Saúde na formação para emancipação e autonomia, juventude e cidadania cultural, produção cultural e a formação do sujeito na contemporaneidade, pesquisa-formação, pesquisa participante, Teoria Crítica.

E-mail: cristina.vermelho@gmail.com 